\title{
Survey and molecular detection of two citrus viroids affecting commercial citrus orchards in the Northern part of Sudan
}

\author{
Mohamed Yousif Adam Abubaker ${ }^{1}$ and Siddig Mohamed Elhassan ${ }^{2}$
}

\author{
${ }^{1}$ Department of Agricultural Sciences, College of Natural Resources and Environmental \\ Studies, University of Juba, Sudan, Phone Number +249 912938537 \\ E. mail: moyousif10@hotmail.com \\ ${ }^{2}$ Department of Crop Protection, Faculty of Agriculture, University of Khartoum, \\ Shambat, Sudan 13314
}

\begin{abstract}
Two extensive surveys and laboratory work were conducted to determine the occurrence of citrus exocortis viroid (CEVd) and hop stunt viroid (HSVd), the causal agent of cachexia (CVd-Ilb) disease in the main citrus growing areas in three states in the northern part of Sudan, viz, Northern, River Nile and Khartoum. For CEVd, all, but one of the examined citrus trees failed to show typical exocortis symptoms. The only symptomatic orange tree encountered in the survey displayed the characteristic CEVd symptoms including tree stunting and bark cracking or bark splitting of the rootstock. While for the cachexia disease, most of the commercial citrus trees were found to be symptomless carriers except mandarin. Symptomatic mandarin trees which were grafted on sour orange rootstock displayed heavy gum impregnation (bark gumming), wood staining and deep bark cracking, in addition to severe stem pitting, bark pegging, twig dieback and yellowing of leaves. Pitting and gum development were usually encountered near the budunion but could spread to other sensitive portions of the infected tree. However, using viroid specific primers and reverse transcription polymerase chain reaction (RT-PCR) approach, both viroids were shown to exist in total RNA preparations from symptomatic and asymptomatic citrus species. Bands of $370 \mathrm{bp}$ and $300 \mathrm{bp}$ corresponding to the full length genomes of CEVd and CVd-Illb, respectively, were detected. The test was positive in 54 for CEVd and 20 for CVd-Ilb out of 200 random samples tested from orange, grapefruit and mandarin. The results indicated that a considerably high percentage of citrus species in the northern part of Sudan, particularly in Khartoum State, were symptomless carriers of both CEVd and CVd-IIb. Being rapid, sensitive and in most cases reliable, the molecular approach could be considered indispensable for viroid detection and in testing programs to produce certified viroid-free planting materials.
\end{abstract}

Key wards: Citrus viroids, Exocortis, Cachexia, Molecular detection.

\section{INTRODUCTION}

Sudan is situated within the citrus belt and hence it possesses great potentialities for citrus industry. The following citrus species comprising the main citrus varieties grown in the country: baladi (Local) lime (Citrus aurantifolia), grapefruit (Citrus paradisi Macf.), sweet orange (Citrus sinensis, Osbeck), lemon (Citrus limon L.) and mandarins (Citrus reticulata, Blanco). The majority citrus species grown commercially in Sudan are grafted onto sour orange (Citrus aurantium, L.) rootstock. Other rootstocks such as baladi lime, rough lemon, adalia lemon and sweet lemon are rarely used in experimental work or in some older plantings (Bove, 1988). At the present time, commercial citrus production spreads to various regions of the country, mainly along the narrow strips of alluvial soils of the River Nile, Blue Nile and White Nile, in addition to Gezira State, Great Kordufan and Great Darfur states (Jebel Marra) and the Southern Sudan. It is also extending to the banks of annual valleys and rivers in which underground water is available for irrigation (Sidahmed and Geneif, 1984, Mahdi, 1996). The orchard is usually composed of a mixture of different citrus varieties with variable relative importance in the different regions. Citrus varieties were first introduced to Sudan at the turn of the 20th century where they were established at the beginning in some of the Government orchards in the northern states. Almost all of them were introduced from USA, Trinidad, Egypt, Palestine, Kenya and Zimbabwe. Earlier introductions were mostly old lines, whose virus status was unknown at the time of 
importation. The estimated area under citrus culture in Sudan amounts to 64,786 feddans (1ha=2.38 Fed) and the average yearly production is about 415,634 tons. Fruits are consumed domestically and the surplus is exported to Saudi Arabia, Arab Gulf States, Turkey and Europe where only small fruited-acid lime and grapefruit are exported with an amount estimated at about 960 tons (Anonymous, 2005).

World-wide, citrus is known to be infected by many virus and virus-like diseases including viroids. Viroids are non-protein-coding small (246-401nt) circular single-stranded RNAs with autonomous replication and are currently classified into two families: Pospiviroidae and Avsunviroidae. Within the family Pospiviroidae, Citrus exocortis viroid (CEVd) belongs to the genus Pospiviroid while Hop stunt viroid (HSVd) is the single member of the genus Hostuviroid. These pathogens are distributed worldwide and infect a large number of hosts including citrus species causing serious yield losses. (Singh et al., 2003; Flores et al., 2005).

The characteristic field symptoms induced by citrus exocortis viroid is a bark scaling and splitting of the sensitive rootstock species although other field symptoms such as dwarfing, leaf epinasty and rugosity, petiole wrinkle and necrosis may also be encountered. Most citrus species grown commercially, such as sweet orange, grapefruit, and Mandarin are tolerant to CEVd (Semancik, 1988).

The definitive symptoms of cachexia disease which is caused by CVd-Ilb, an HSVd variant include stem pitting and gum impregnation of the bark in sensitive cultivars.

Traditionally viroids can be detected by indexing on sensitive biological indicator plants, but bioassay even on suitable test plants takes time and is not so reliable (Hanold et al., 2003). Later, detection of viroids has been advanced and facilitated by the use of many molecular techniques such as reverse transcription-polymerase chain reaction (RT-PCR) approach (Levy et al., 1992; Yang et al., 1992; Villalobos et al., 1997).

The main citrus groves in Sudan are thought to be heavily inflicted with virus and virus-like diseases. This has been implicated from a number of disease surveys conducted by reputed foreign specialists in eastern, western, central and northern Sudan during 1964-1988 (Childs, 1964; Krezdorn, 1983; Bove, 1988) for the benefit of the Sudanese Ministry of Agriculture. Some of these diseases were diagnosed on the basis of their characteristic symptoms, such as cachexia, gummy bark, Kassala disease (bark gumming of grapefruit), psorosis, popcorn, stubborn, woody gall-vein enation while others ( tristeza and exocortis) were only suspected to exist since their visual symptoms were not fully diagnostic.

Serious research on citrus virus and viroid diseases in Sudan is very meager and at its infant stage. In addition to above mentioned surveys, a comprehensive research work was conducted recently by Abubaker (2009) on the detection and diagnosis of important citrus virus and virus-like diseases in Sudan using serological and molecular techniques. However, Mohamed (2009) claimed the presence of CEVd and lor other citrus viroids, by using only citron 861-S1 as an indicator species.

This paper is intended to establish the occurrence and distribution of both CEVd and CVd-IIb in commercial citrus orchards in Khartoum, River Nile and Northern states of Sudan through field surveys for visual diagnostic symptoms and molecular detection using RT-PCR approach.

\section{MATERIALS AND METHODS}

Survey and viroids source. The main objectives of the survey were to study the symptomatology of the two naturally occurring viroid diseases in the three citrus species, namely, sweet orange, mandarin and grapefruit, and to collect representative samples for further etiological work. Two surveys were made in the main citrus growing areas of Khartoum, River Nile and Northern States during 2005-2006. The surveys covered eleven locations (Table1 and Fig.1) where a total of 760 trees from 60 orchards were closely inspected for typical exocortis and cachexia diseases. A total of 200 samples were collected randomly regardless of whether the trees showed viroid-like symptoms. The samples consisted of leaf materials and young shoots from new flushes in the four quadrants of the selected trees. The citrus species from which the samples were collected consisted of orange, grapefruit and mandarin.

The field diagnosis was performed by closely examining the obvious external symptoms including existence of bark cracking, tree stunting, twig dieback and yellowing of leaves. Characteristic internal symptoms displaying pitting and pegs development and gum impregnation were also examined on both bark and wood by excising a window of $3.5 \times 1.5$ inches from the bark at the bud union region and scratching-off the bark with a sharp knife. Photographs of representative symptoms were taken. 
Table1. Localities of commercial citrus orchards surveyed for citrus exocortis and CVd-Ilb viroids in the northern part of Sudan

\begin{tabular}{|c|l|c|c|}
\hline States & Locality & $\begin{array}{c}\text { Number of } \\
\text { Surveyed } \\
\text { Orchards }\end{array}$ & $\begin{array}{c}\text { Number of } \\
\text { Trees } \\
\text { Examined }\end{array}$ \\
\hline \multirow{3}{*}{ Northern } & Gureir & 10 & 100 \\
& Merowe & 5 & 50 \\
\hline \multirow{3}{*}{ River Nile } & Ketiab & 7 & 70 \\
& Fadnia & 6 & 60 \\
& Shendi & 10 & 150 \\
& Bagrossa & 4 & 40 \\
\hline \multirow{3}{*}{ Khartoum } & Shambat & 2 & 75 \\
& Faki Hashim & 5 & 70 \\
& Tumaniat & 5 & 70 \\
& Suba & 5 & 50 \\
& Mugran & 1 & 25 \\
& & & \\
\hline \multirow{2}{*}{ Total } & & & \\
& & & \\
& & & \\
& & & \\
\hline
\end{tabular}

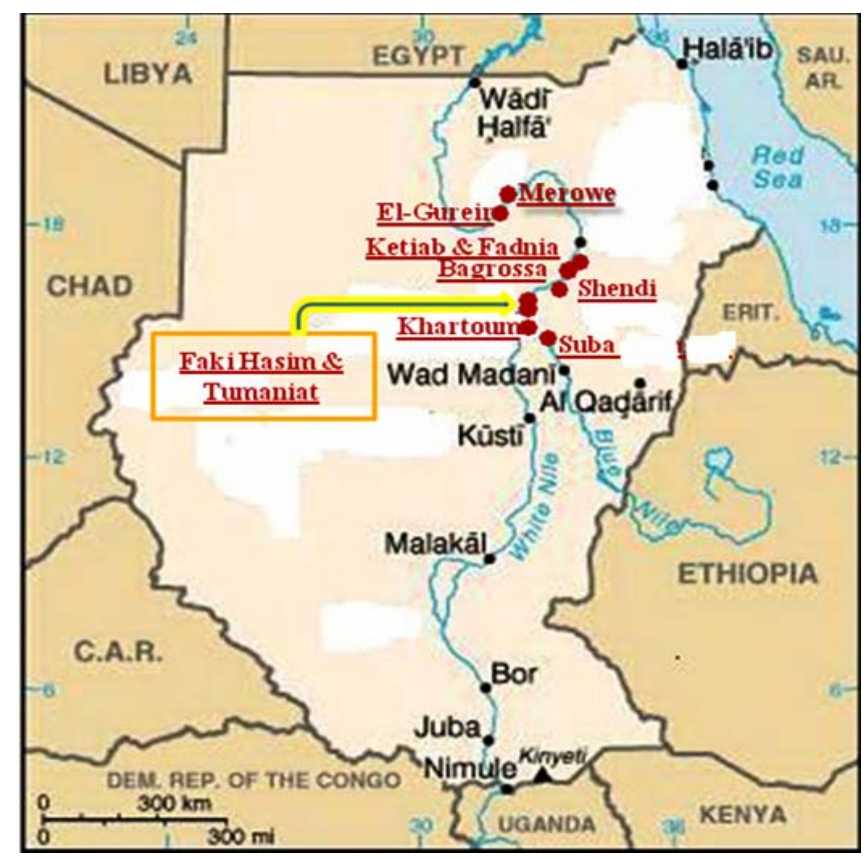

Fig. 1. Locations of commercial citrus orchards surveyed for citrus viroid in Khartoum (Mugran, Shambat, Faki Hashim, Tumaniat and Suba), River Nile (Shendi, Ketiab, Fadnia and Bagrossa) and Northern (Merowe and El-Gureir) states.

Table 2. Primers sequences used for the amplification of the desired fragment of citrus exocortis viroid (CEVd) and citrus cachexia viroid (CVd-Ilb)

\begin{tabular}{|c|c|c|c|c|}
\hline Viroid & Primer & $\begin{array}{l}\text { Product } \\
\text { size (bp) }\end{array}$ & Sequences & Reference \\
\hline \multirow[t]{2}{*}{ CEVd } & CEVd-for 1 & \multirow{2}{*}{370} & $>5^{\prime}$ GGG GGA AGA AGT CCT TC < <' & \multirow[t]{2}{*}{ Rigden and Rezaian (1992) } \\
\hline & CEVd-rev 1 & & $\begin{array}{l}>5 \text { ' CCG CCT CTT TTT TCT TTT CCT GCC } \\
\text { TGC <3' }\end{array}$ & \\
\hline \multirow[t]{2}{*}{ CVd-IIb } & CVd-IIb for & \multirow{2}{*}{300} & $>5^{\prime}$ TTG CCC CGG GGC TCC TTT CTC <3' & \multirow[t]{2}{*}{ Villalobos et al. (1997) } \\
\hline & CVd-Ila/b rev & & $>5^{\prime}$ CTC TTC TCA GAA TCC AGC GA<3' & \\
\hline
\end{tabular}

\section{Molecular detection}

Nucleic acid extraction. Starting from $100 \mathrm{mg}$ plant material, total RNA was extracted from fresh leaves and young shoots using Invisorb ${ }^{\circledR}$ Spin Plant RNA Mini Kit (Invitek, Germany) following the manufacturer's protocol. RNA was eluted in $50 \mu \mathrm{l}$ of elution buffer. Extracted RNA samples were then stored in small aliquots at $-80^{\circ} \mathrm{C}$.
Primers. A pair of two different oligonucleotide primers were used to amplify the full length genome of each of CEVd (370bp) and CVd-IIb (300 bp) respectively. The characterization of the four primers was given in Table (2).

Complimentary DNA Synthesis (cDNA). cDNA was synthesized using total nucleic acid extracted from citrus leaves and young shoots as templates. The 
RNA was reverse-transcribed into cDNA using a reverse transcriptase enzyme (M-MMLV Reverse Transcriptase) in the presence of the CEVd or CVdIlb reverse primers.

\section{Reverse Transcription Polymerase Chain Reaction (RT-PCR) Amplification RT-PCR was carried out for each viroid separately. The amplification were performed with Taq DNA polymerase in a Robocycler Gradient 96 (Stratagene) according to the following programs (35 cycles): for CEVd 2 min at $94^{\circ} \mathrm{C}, 45$ second at $94^{\circ} \mathrm{C}, 45$ second at $50^{\circ} \mathrm{C}, 1 \mathrm{~min}$ at $72^{\circ} \mathrm{C}$. While for CV-IIb, $2 \mathrm{~min}$ at $94^{\circ} \mathrm{C}, 1 \mathrm{~min}$ at $94^{\circ} \mathrm{C}, 1 \mathrm{~min}$ at $55^{\circ} \mathrm{C}, 1.5 \mathrm{~min}$ at $72^{\circ} \mathrm{C}$. Then a final extension of 5 and $7 \mathrm{~min}$ at $72^{\circ} \mathrm{C}$ was performed for CEVd and CV-Ilb respectively. The amplified DNA fragments were subjected to electrophoresis in a 1.2\% agarose gel and visualized under 312 nm UV-light.}

\section{RESULTS}

Field survey: Based on noticeable visual and internal symptoms displayed by the different citrus species inspected, all surveyed trees showed no visible symptoms of CEVd infection except one old sweet orange tree in Shendi area. This symptomatic tree, however, exhibited typical CEVd symptoms consisting of bark cracking (splitting) of the rootstock accompanied with tree stunting (Fig.2). The pronounced symptoms associated with cachexia disease, on the other hand, were only encountered on mandarin trees grafted on sour orange rootstock. Characteristic symptoms consisting of heavy gum impregnation (bark gumming), wood staining and deep bark cracking in addition to severe stem pitting and bark pegging (large or small pegs) were observed on mandarin trees above the budunion with sour orange rootstock in all the surveyed areas (Fig.3). Moreover, twig dieback and yellowing of leaves were also observed in association with cachexia infection (Fig.3). In certain locations, symptoms were often severe with abundant bark gumming and stem pitting extending high above the budunion. In some severe cases bark cracking and tree stunting were both evident in the same tree. Depending on visual inspection and classical diagnostic field symptoms, cachexia disease was strikingly prevalent and recorded an average incidence of $76.3 \%$, while citrus exocortis viroid (CEVd) was only encountered in one tree out of 760 in River Nile State. The incidence of cachexia disease in Northern, River Nile and Khartoum states was $5 \%, 95 \%$ and $90 \%$, respectively.

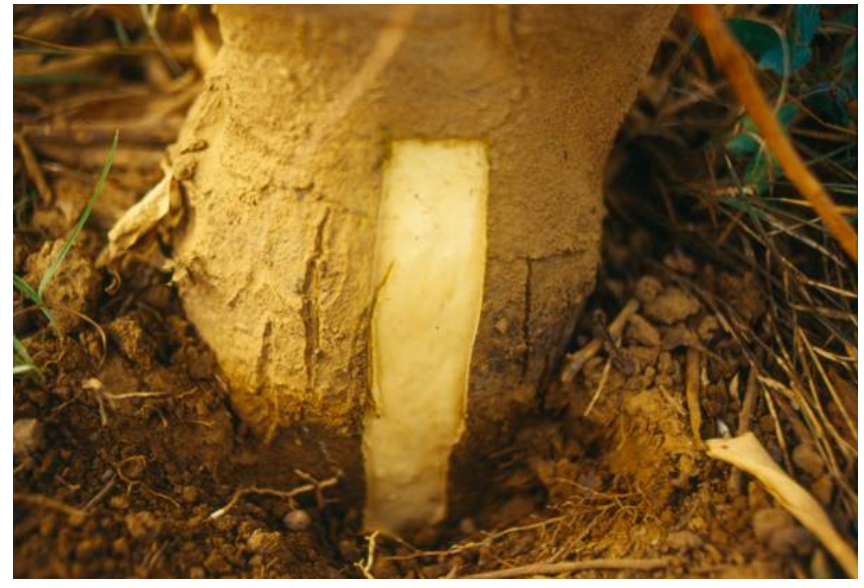

Fig. 2. Prominent bark cracking and splitting on an unknown rootstock of a sweet orange tree showing typical symptoms of Citrus exocortis viroid (Shendi, River Nile State).

\section{Molecular detection}

RT-PCR. The two viroids targeted in this paper were identified on the basis of the size of PCR amplification products using specific viroid primers. Using RT-PCR approach, CEVd and CVd-Ilb were detected in total RNA preparations from symptomatic and non-symptomatic citrus species. Out of 200 test samples CEVd was detected in 54 samples (27\%) while CVd-Ilb was found in 20 samples (10\%) comprising orange, mandarin and grapefruit grafted onto sour orange rootstock (Table 3). Citrus exocortis viroid was detected in the three surveyed states, while CVd-Ilb was found only in River Nile and Khartoum states but was not detected in Northern State. When using specific viroid primers, bands of $370 \mathrm{bp}$ and $300 \mathrm{bp}$ corresponding to the full-length genome of CEVd and CVd-Ilb, respectively, were detected in the positive RT-PCR amplicons, whereas the healthy controls were deficient of such bands (Fig. 4 and 5) 
Agric. Biol. J. N. Am., 2010, 1(5): 930-937
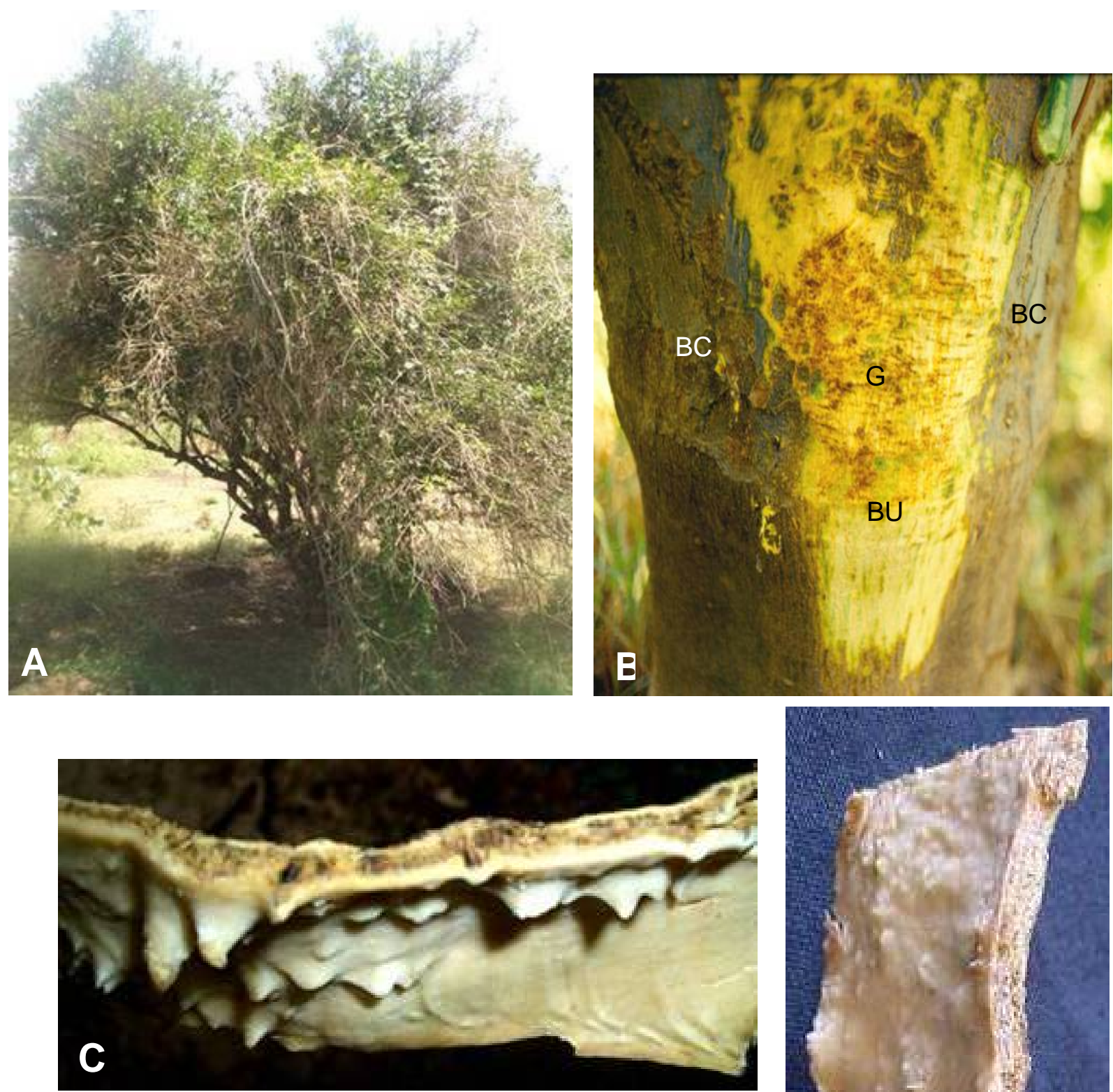

Fig. 3. Characteristic symptoms of cachexia disease on mandarin tree on sour orange rootstock showing A: severe tree stunting, twig dieback, yellowing of leaves and horizontal branch growth; B: bark cracking (BC) and gumming (G) above the budunion (BU) extending considerably high above budunion; C: Inner cambial face of bark removed across budunion of mandarin tree showing severe gum impregnation on the edge and prominently large pegs. Sometimes needle-like pegs can also be found (D) (El Faki Hashim, Khartoum State).

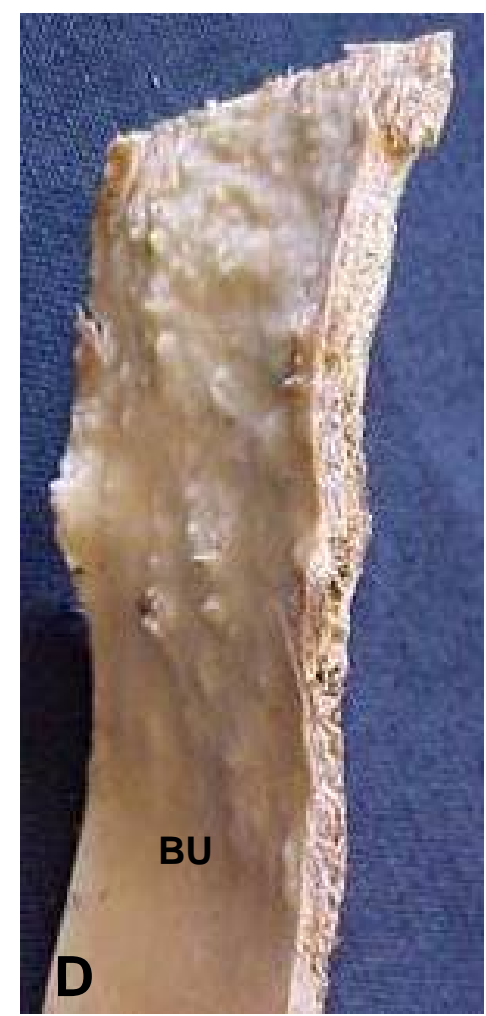


. Table 3 Detection of citrus exocortis and cachexia viroids in citrus orchards in Northern, River Nile and Khartoum states using reverse transcriptase- polymerase chain reaction (RT-PCR) approach with specific viroid primers

\begin{tabular}{|c|c|c|c|c|c|}
\hline Location & $\begin{array}{c}\text { Number } \\
\text { of } \\
\text { surveyed } \\
\text { orchards }\end{array}$ & Source trees & $\begin{array}{c}\text { Number of } \\
\text { test } \\
\text { samples }\end{array}$ & $\begin{array}{c}\text { CEVd-positive } \\
\text { Samples }\end{array}$ & $\begin{array}{c}\text { Cachexia (CVd-Ilb)-positive } \\
\text { Samples }\end{array}$ \\
\hline Northern State & 8 & $\begin{array}{c}\text { orange } \\
\text { mandarin and } \\
\text { grapefruit }\end{array}$ & 40 & 8 (6 orange, 2 mandarin) & - \\
\hline River Nile State & 8 & $\begin{array}{c}\text { orange, } \\
\text { mandarin } \\
\text { and } \\
\text { grapefruit }\end{array}$ & 80 & (orange) & Orange, 4 mandarin) \\
\hline Khartoum State & 10 & $\begin{array}{c}\text { Orange, } \\
\text { mandarin and } \\
\text { grapefruit }\end{array}$ & 80 & $\begin{array}{c}36 \text { (12 orange, } 18 \\
\text { mandarin, } \\
6 \text { grapefruit) }\end{array}$ & 27 \\
\hline
\end{tabular}

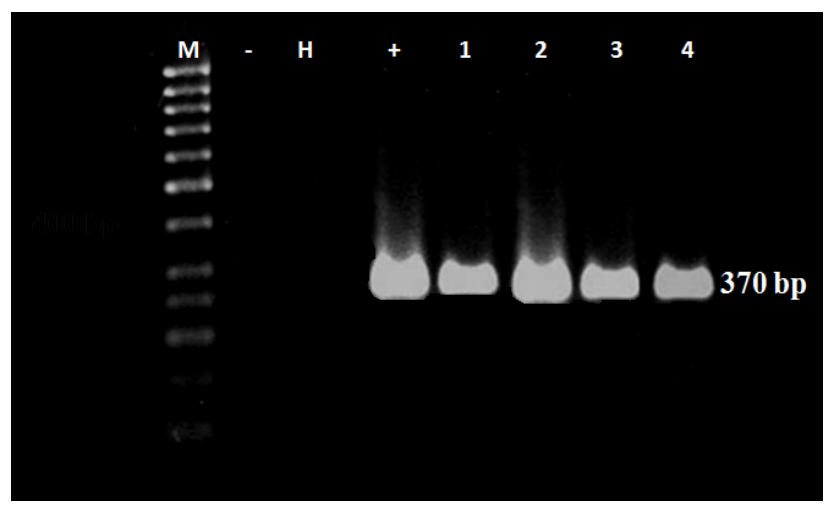

Fig. 4. Detection of Citrus exocortis viroid (CEVd) in 4 citrus trees using RT-PCR assay with specific CEVd primers followed by electrophoresis analysis. Lane $M, 50$ bp DNA ladder; -, water; $H$ healthy citrus; +, positive control; 1-4, tested samples. Positive results were indicated by appearance of bands at $370 \mathrm{bp}$ position.

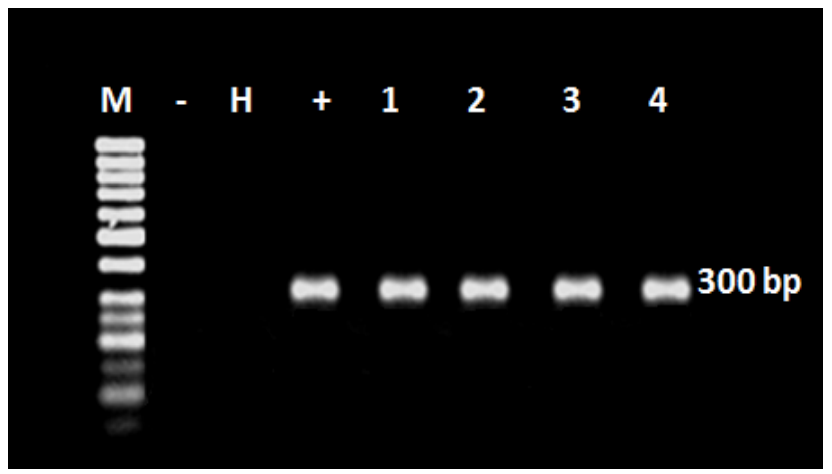

Fig. 5. Detection of CVd-Ilb in four citrus samples using RT-PCR assay with specific CVD-Ilb primers followed by electrophoresis analysis. Lane M, 50 bp DNA ladder; -, water; $\mathrm{H}$, healthy citrus; +, positive control; 1-4, tested citrus samples. Positive results were recognized by the appearance of CVd-IIb- specific bands at $\mathbf{3 0 0}$ bp position.
Sixteen out of two hundred test samples showed mixed infections with the two detected pathogens (viz. CEVd and CVd-IIb) (Table 3). Ten samples collected from orange trees were found to carry the two pathogens, while the remaining six double infections were collected from mandarin. All these mixed infections were only encountered in River Nile and Khartoum states (Table 3).

\section{DISCUSSION}

Under the present citriculture situation in Sudan, where sour orange is the predominantly used rootstock, it seems possible to obtain positive clues on detection and diagnosis of cachexia disease but not of citrus exocortis depending largely on visual characteristic symptoms. Although characteristic symptoms of cachexia disease were readily diagnosed in mandarin with sour orange rootstock, sweet orange and grapefruit trees failed to display such visual symptoms. This is perceivable since the latter two citrus species are considered as important symptomless carriers of the disease where infection is revealed when they are grafted on susceptible rootstocks such as Citrus macrophylla, langpur lime or sweet lime (Bove, 1995). The strikingly high incidence of cachexia (76.3\%) encountered in mandarin during the survey was interesting but it could probably be attributed to long perpetuation of low level infections in the original introductions through cross contamination taking place under the traditional less hygienic grafting procedures. In comparison, the Northern State showed relatively 
very low incidence (5\%) of cachexia. This could be explained by the fact that most mandarin trees which were particularly more affected by the River Nile flooding in 1988 in Northern State were later replaced by new mandarin stocks. So, at the time of the survey most of the young mandarin trees were without detectable symptoms. Similarly, Bove (1988) during his survey for citrus virus and virus-like diseases in Sudan including large parts of the presently surveyed areas recorded high infection (>50\%) of mandarin with cachexia disease.

Virtually, the almost total absence of citrus exocortis viroid (CEVd) disease in the commercial citrus groves in the three surveyed states was understandable. This could be interpreted based on the fact that characteristic symptoms would not develop in citrus species grafted on sour orange rootstock (the predominant rootstock in Sudan) and the infection might remain latent (Roistacher, 1991). However, the only symptomatic sweet orange tree positively diagnosed as carrying CEVd infection might have been grafted on a susceptible rootstock other than sour orange. Similar results have previously been reported independently by Childs (1964), Krezdorn (1983) and Bove (1988) during their surveys conducted in different parts of Sudan. The only exceptions encountered during these surveys, however, were one white march grapefruit tree grafted on citron (Childs, 1964) and some experimental citrus trees where rootstocks other than sour orange were tried at Hudeiba Research Station in River Nile State (Krezdorn, 1983).

The use of RT-PCR approach revealed a considerably high natural occurrence of CEVd $(27 \%)$ in the three states while cachexia disease (CVd-IIb) recorded a lower incidence (10\%) and was found only in Khartoum and River Nile states. These results on molecular detection indicated that all the inspected citrus species grafted on sour orange rootstock (sweet orange, grapefruit and mandarin) were symptomless carriers of CEVd while only sweet orange and grapefruit were symptomless carriers of cachexia disease due to the same scion rootstock combinations. The disparity between the two infection levels as obtained by visual assessment and molecular detection for cachexia disease could be attributed to the low numbers of mandarin trees that were randomly included in the test. Thus, the selection based only on visual examination is usually incapable of establishing the health status of citrus trees because good-looking asymptomatic trees might be symptomless carriers of disease agents.
Therefore, periodical molecular indexing is required to diagnose the above viroid diseases in the commercial orchards. Under this natural situation, it must be emphasized that the existence of both viroids in symptomless citrus trees needs special care from farmers when they perform certain cultural practices, especially budding and pruning, since viroids are easily transmitted via contaminated environment. So, farmers and agricultural extensionists alike must be alert to curtail the dissemination of these serious viroid diseases.

The natural mixed infection with CEVd and HSVd (CVd-Ilb) in one citrus tree is a known phenomenon. This is attributable to the less hygienic procedures of propagation and regular agronomic practices such as pruning and to the long potential life of citrus trees in the open field. Previous studies have demonstrated that citrus viroids are present as a population in any citrus tree especially when they are closely related such as CEVd and HSVd (CVd-IIb) (Eiras et al., 2006). Semancik et al. (1988) reported that citrus harbours the largest collection of viroids than any single plant group. Malfitano et al. (2005) during his survey for citrus viroid diseases in Southern Italy, reported that the most frequent viroid combination under field conditions was that of CEVd, HSVd (CVd$\mathrm{IIb})$ and CVd-III (40.2\%).

This work represents the first authentication of the natural occurrence of CEVd and HSVd (CVd-Illb) in our commercial citrus orchards in Sudan. The RTPCR approach appears to be a rapid and versatile technique that can be used for detection and diagnosis of the present and other unreported viroid diseases, especially in cases of latent infections and in quarantine inspection. This would be important for citrus materials intended for use in budwood certification programs and it can successfully replace all the efforts and inconveniences of biological indexing with substantial saving of money and time. It seems imperative however, to further establish the identity and complete the characterization of Sudanese isolates of both viroids by cloning and sequencing of the amplified viroid genomes.

\section{REFERENCES}

Abubaker, M. Y. A (2009). Detection and diagnosis of important virus and virus-like diseases in commercial citrus orchards in some tropical areas of Sudan. Ph.D. Thesis, University of Khartoum, Sudan.

Anonymous (2005). A yearly report of Federal Horticultural Department, Ministry of Agriculture and Forestry, Khartoum, Sudan. 
Bove, J. M (1988). Virus and virus-like diseases of citrus in Sudan. A report to the Government of Sudan, FAO.

Bove, J. M (1995). Virus and virus-like diseases of citrus in the Near East region. FAO-Rome, 518 pp.

Childs, J. F. L (1964).Observations on virus and other diseases of citrus in Sudan. (A report to the Ministry of Agriculture, Sudan).

Eiras, M., Targon, M. L., Fajardo, T. V. M., Flores, R., and Kitagima, E. W (2006). Citrus exocortis viroid and hop stunt viroid doubly infecting grapevines in Brazil. Fitopathol. Bras. Volume 31.

Flores, R., Hernandez, C., Martinez De Alba, A. E., Daros, J.A. and Diserio, F (2005). Viroids and viroid-host interactions. Annual Review of Phytopathology 43:117139.

Hanold. D., Semancik, J. S., and Owens, R. A (2003). Polyacrylamide gel electrophoresis. In: Viroids (A. Hadidi, R. Flores, J. W. Randles and J. S. Semancik, eds. Pages 95-102. CSIRO, Collingwood VIC, Australia.

Krezdorn, A. H (1983). Report of visit to Sudan to review fruit tree research program and related factors. WSARP Publication, No. 17.

Levy, L., Garnsey, S. M., and Hadidi, A (1992). Reverse transcription polymerase chain reaction assays for the rapid detection of citrus viroids using multiplex primer sets. Proc. Int. Soc. Citriculture 2, 800-803.

Malfitano, M., Barone, M., and Alioto, D (2005). Survey of citrus viroids in Campania (Southern Italy) Plant Dis. 89,434 .

Mahdi, E. M (1996). Seasonal changes in the concentration of some micronutrients in leaves of sweet orange and grapefruit varieties grown in Shambat. U. of K. J. Agric. Sci. 4 (2), 91-103.

Mohamed, M. E. 2008. A note on the occurrence of citrus exocortis viroid and/or of citrus viroids in local citrus cultivars in the Sudan. U. of K. J. Agric. Sci. 16 (3) 490-495.

Rigden, J. E., Rezaian, M. A (1992). In vitro synthesis of an infectious viroid: Analysis of the infectivity of monomeric linear CEVd. Virol. 186, 201-206.

Roistacher, C. N (1991). A historical review of the major graft-transmissible disease of citrus. FAO, Rom 88 pp.

Semancik, J. S (1988). Citrus exocortis disease. 1976 to 1986. In: Proc. $7^{\text {th }}$ Conf. of IOCV. Pp. 136-151. Riverside, IOCV.

Semancik, J. S., Roistacher, C. N., Rivera- Bustamante, R., and Duran-Vila, N (1988). Citrus cachexia viroid, a new viroid of citrus: relationship to viroids of exocortis disease complex. J. Gen. Virol. 69, 3059-3068.

Sidahmed, O. A., and Geneif, A. A (1984). Performance of citrus in the irrigated heavy clay soils of central Sudan. 1 Lemon. Acta Hort $8^{\text {th }}$ African Symposium on Hort. Crops. 143, 247-255.

Singh, R. P., Ready, K. F. M. and Nie, X (2003). Biology. In Viroids (A. Hadidi, R. Flores, J. W. Randles, and J. S. Semancik, eds.). Pages 30-48. CSIRO, Collingwood VIC, Australia.

Villalobos, W., Rivera, C., and Hammond, R.W (1997). Occurrence of Citrus viroids in Costa Rica. Rev. Bio. Trop.45, $983-987$.

Yang, X., Hadidi, A., and Garnsey, S. M (1992). Enzymatic DNA amplification of citrus exocortis and cachexia viroids from infected citrus hosts. Phytopathol. 82, 279-285. 